\title{
Tobacco consumption and asbestos exposure in patients with lung cancer: a three year prospective study
}

\author{
G HILLERDAL,' EVA KARLEN,' AND T ÅBERG ${ }^{2}$ \\ From the Departments of Lung Medicine ${ }^{1}$ and Thoracic Surgery, ${ }^{2}$ University Hospital, Uppsala, Sweden
}

ABSTRACT During the three years 1979-81, all patients with bronchial carcinoma of World Health Organisation types I to IV were given a questionnaire to determine occupation, smoking habits, and exposure to asbestos. Chest $x$ rays were screened for the presence of pleural plaques. Of the men, $96.2 \%$ were current or ex-smokers, as were $71 \%$ of the women. In those who had never smoked $70 \%$ had an adenocarcinoma. In smokers the risk of getting other types was greater, but the risk of getting an adenocarcinoma was also considerably increased compared with the normal population. Of the men, $35.8 \%$ were occupationally exposed to asbestos and $15.6 \%$ were carriers of radiological plaques, a frequency five to six times greater than expected. Practically all asbestos exposed patients with lung tumours were smokers or ex-smokers and their total tobacco consumption was as high as that of non-exposed patients. The average latency from first exposure to asbestos to diagnosis of the lung tumour was 37 years. Even if strict regulations are warranted for the use of asbestos, this cannot prevent future asbestos cancers resulting from exposure that has already occurred. Elimination of smoking seems the only way to reduce such tumours.

Though tobacco smoking is the most important cause of bronchial carcinoma, other factors can contribute. In an earlier retrospective study from the county of Uppsala during a 16 year period the importance of asbestos seemed to be increasing with time. ${ }^{1}$ To investigate further the importance of various aetiological factors, we undertook a prospective study.

\section{Material and methods}

All patients with bronchial carcinoma of World Health Organisation types I to IV or undifferentiated, diagnosed between 1 January 1979 and 31 December 1981 and seen at the department of lung medicine were included together with those seen at the department of thoracic surgery, University Hospital, Uppsala, from 1 September 1980 to 31 December 1981. The patients thus consisted of one group of patients from the county of Uppsala and one from a much larger region who had been refer-

Received 13 August 1982

Accepted 6 December 1982 red for evaluation and treatment.

All patients were given a questionnaire to assess lifetime smoking - that is, habits, occupation, exposure to various agents including asbestos, and earlier diseases, as well as other information. One cigarette was counted as $1 \mathrm{~g}$ of tobacco, and one cigar as $5 \mathrm{~g}$. To qualify as a person who had never smoked, the subject must not have smoked more than $1000 \mathrm{~g}$ during his lifetime. Chest $x$ rays were scrutinised for pleural plaques. Whenever necropsy or an operation was performed, the pleurae were inspected for such plaques.

In most cases the questionnaire was verified by a personal interview by one of us. The questionnaire is based on the British Medical Research Council (BMRC) questionnaire and has been extensively used before and has shown good results when compared with personal interviews.

\section{Results}

Of the 346 men, 134 were from the county of Uppsala and 212 from the catchment region. The only difference of importance between the two 380 
groups of men was that in the county group the average age was a little higher although not statistically significant. No other factor discussed here (relative incidence of tumour types, exposure to asbestos, amount of pleural plaques, and smoking habits) differed significantly, and therefore the groups are analysed as a whole. The same was true for the 89 women- 32 from the county and 57 from the region.

Except for a few elderly men, in whom further clinical investigations were not indicated and whose diagnosis was based on radiological findings and cancer cells in the sputum, all cases were classified as WHO types I to IV. Fourteen men $(4.0 \%)$ and five women $(5.6 \%)$ answered the questionnaire incompletely or not at all.

\section{WHO TYPES}

There was a sex difference in WHO types, with a preponderance of squamous cell carcinomas among the men and of adenocarcinomas among the women (table 1).

\section{SMOKING HABITS}

Almost all men $(96.2 \%)$ and most women $(71 \%)$ were smokers or ex-smokers. There were some differences in sex and type of tumour in relation to smoking habits (table 2). Adenocarcinoma was the most common type among non-smokers. More specifically, of the 13 men who had never smoked, nine $(69 \%)$ had a tumour of WHO type III, as did 19 of 26 non-smoking women (73\%). Among those with squamous cell carcinomas, there was only one man who had never smoked, whereas there were six women. As for passive smoking, no questions were asked specifically about this in most cases, but of eight women (six with adenocarcinoma) who had

Table 1 WHO types of lung cancer (per cent) in the study

\begin{tabular}{lcc}
\hline & Men & Women \\
\hline WHO I (squamous cell) & $52 \cdot 9$ & 27 \\
WHO II (small cell) & $19 \cdot 4$ & 21 \\
WHO III (adenocarcinoma) & $18 \cdot 8$ & 49 \\
WHO IV (Large cell anaplasia) & $5 \cdot 5$ & 2 \\
Undifferentiated & $3 \cdot 5$ & \multicolumn{1}{c}{} \\
Total & 100 & 100 \\
\hline
\end{tabular}

Table 2 Percentage of patients with lung cancer who had never smoked

\begin{tabular}{lcc}
\hline & Men & Women \\
\hline WHO I & 0 & 25 \\
WHO II & $3 \cdot 0$ & 6 \\
WHO III & $13 \cdot 8$ & 43 \\
WHO IV & $10 \cdot 5$ & 0 \\
Total & $3 \cdot 8$ & 29 \\
\hline
\end{tabular}

never smoked, seven had, or had had, a husband who was a heavy smoker.

The total life consumption of tobacco among the men averaged $226 \mathrm{~kg}$, with only minor variations between those with various histological types of tumours; the smokers with adenocarcinomas were as heavy smokers as those with other types. Altogether 101 men (29\% of the total) were exsmokers-that is, they had stopped at least one year before the tumour was diagnosed. The average duration of abstinence among the ex-smokers was 10.5 years. The smoking and ex-smoking women had a lower tobacco load than the men, on average $170 \mathrm{~kg}$. Five were ex-smokers.

\section{ASBESTOS EXPOSURE AND PLEURAL PLAQUES}

In all, $38.5 \%$ of the men claimed exposure to asbestos, in all cases of occupational origin. WHO types I and III were a little more common among those exposed to asbestos, but this was not statistically significant (table 3). The same was true for pleural plaques; 54 patients $(15.6 \%)$ had radiological pleural plaques, eight of whom denied exposure to asbestos. In all cases where they could be checked at necropsy or operation plaques which had been diagnosed on chest $x$ ray were confirmed, and an additional five cases were found.

Only three of the patients had radiological pulmonary fibrosis. The asbestos exposure was most often intermittent and never heavy, the most common occupations being plumbers, builders and electricians (table 4). Four of the women had been occupationally exposed to asbestos, one of whom also had pleural plaques.

Only four patients with pleural plaques or asbestos exposure, or both, and bronchial carcinoma were never-smokers. Interestingly, all four had adenocarcinomas. The tobacco consumption among the asbestos group was $229 \mathrm{~kg}$, not statistically different from the other groups' $222 \mathrm{~kg}$.

As already mentioned, there were no significant differences between the asbestos group and the others concerning WHO subtypes. There was, however, an almost significant difference in the distribution of tumours between different locations (table 5). Among those not exposed to asbestos the ratio of

Table 3 Asbestos exposure and pleural plaques in men with lung cancer (per cent)

\begin{tabular}{lll}
\hline & Asbestos exposure & Pleural plaques \\
\hline WHO I & 42.1 & 16.4 \\
WHO II & 29.9 & 13.4 \\
WHO III & 38.5 & 15.4 \\
WHO IV & 26.3 & 15.8 \\
Undifferentiated & 25.0 & 16.7 \\
Total & 35.8 & 15.6 \\
\hline
\end{tabular}


Table 4 Occupations, pleural plaques, and asbestos exposure in patients with bronchial carcinoma

\begin{tabular}{|c|c|c|c|c|c|}
\hline \multirow[t]{2}{*}{ Occupation } & \multicolumn{2}{|l|}{ Exposed } & \multicolumn{2}{|c|}{ Non-exposed } & \multirow[t]{2}{*}{ Description of exposure } \\
\hline & $\begin{array}{l}\text { With } \\
\text { plaques }\end{array}$ & $\begin{array}{l}\text { Without } \\
\text { plaques }\end{array}$ & $\begin{array}{l}\text { With } \\
\text { plaques }\end{array}$ & $\begin{array}{l}\text { Without } \\
\text { plaques }\end{array}$ & \\
\hline Building workers & 16 & 26 & 1 & 7 & $\begin{array}{l}\text { Insulation, tearing down houses, } \\
\text { spraying asbestos, etc }\end{array}$ \\
\hline Plumbers & 5 & 3 & 0 & 0 & $\begin{array}{l}\text { Insulation of hot water tubes; replacing } \\
\text { insulation, etc }\end{array}$ \\
\hline Electricians & 0 & 1 & 0 & 0 & Insulation, etc \\
\hline Painters & 1 & 2 & 0 & 4 & $\begin{array}{l}\text { Asbestos in paints; cleaning of dust } \\
\text { before painting; close to asbestos } \\
\text { workers }\end{array}$ \\
\hline \multicolumn{6}{|l|}{ Repairmen and fitters: } \\
\hline Of cars & 5 & 10 & $\mathbf{0}$ & 0 & Brake lines, gear boxes \\
\hline Of engines & 1 & 8 & 0 & 3 & Insulation of steam engines, etc \\
\hline Others & 3 & 2 & - & - & Brakes, insulation, etc \\
\hline Metal workers, platers, etc & 5 & 11 & 0 & 11 & Protection in welding, insulation, etc \\
\hline Scrap iron workers & 1 & 0 & 0 & 1 & Scrapping tubes and steam engines, etc \\
\hline Transportation, storage work & 2 & 4 & - & 一 & Transportation and storage of asbestos \\
\hline Others & 2 & 6 & - & - & \\
\hline Total & 42 & 76 & 12 & - & \\
\hline
\end{tabular}

Table 5 Distribution of lung tumours in men (per cent)

\begin{tabular}{lll}
\hline & $\begin{array}{l}\text { Not exposed to } \\
\text { asbestos }\end{array}$ & $\begin{array}{l}\text { Exposed to } \\
\text { asbestos }\end{array}$ \\
\hline $\begin{array}{l}\text { Central bronchi and } \\
\text { trachea }\end{array}$ & 13.1 & 8.0 \\
Upper and middle lobes & 57.0 & 49.2 \\
Lower lobes & 29.9 & 42.3 \\
\hline
\end{tabular}

upper to lower lobes as the tumour site was about 2 to 1 ; among those exposed, almost 1 to 1 . The difference is not statistically significant, however, unless the women are included, and then the significance is at a low level $(\mathrm{p}<0.05)$.

The latency from the first exposure to asbestos to the diagnosis of the tumour varied from nine to 60 years (average $37 \cdot 1$ ).

FACTORS OTHER THAN SMOKING AND ASBESTOS There were 14 miners and several metal workers in the series. There were also several in occupations where they were likely to have become exposed to asbestos but who denied this. These findings are hard to evaluate. Finally, there was one man who had been heavily exposed to radiation during $x$ ray investigation of minerals 40 years before diagnosis of a small cell carcinoma of the lung.

As for the women, one had never smoked but had a squamous cell carcinoma of the lung. In her youth she had been treated with an arsenic compound in fairly high doses and had earlier had multiple squamous cell carcinomas removed from her skin, but the lung tumour was considered a primary. In two women the tumour developed in the context of known pulmonary fibrosis.

\section{Discussion}

This study has again shown the overwhelming importance of smoking in the aetiology of lung cancer. At least in Sweden, however, other factors, and especially asbestos, make an important contribution, despite the fact that the region investigated possesses no wharves or other heavy industries using asbestos.

The smoking habits and total tobacco consumption are similar to those noted in earlier investigatipns from the county. ${ }^{12}$ A non-smoker with a bronchial carcinoma most likely has an adenocarcinoma. The smoker, on the other hand, will get a tumour of type I or II, but the risk of getting an adenocarcinoma is also higher than that of a non-smoker.

Stopping smoking reduces the risk of lung cancer, but even after 15 years of abstinence the risk is nearly twice that of a non-smoker. ${ }^{3}$ This fits well with the present series, where the sizeable proportion of ex-smokers, most of whom had stopped smoking for more than 10 years, shows that a considerable risk remains. Unfortunately, the importance of passive smoking was not considered when the investigation started, but of the eight women who had never smoked and were asked about this, seven had a husband who was a heavy smoker. This indicates that the findings from Japan, that wives of heavy smokers run an increased risk of developing lung cancer, ${ }^{4}$ also holds true for Sweden. This might have legal implications in occupations where passive smoking occurs-for example, in restaurants.

Preliminary findings in the County of Uppsala show that about $6 \%$ of men aged over 40 admit exposure to asbestos (G Hillerdal and P Malmberg. 
in preparation). Even if patients with a lung tumour are more likely to recollect exposure to various agents, the number of those who have been exposed to asbestos is at least five times higher in a lung cancer series than in the population as a whole. The same holds true for pleural plaques, the radiological frequency of which has been estimated to be about $2-3 \%$ in the men over 40 in the county. ${ }^{56}$ That about $20 \%$ of those with pleural plaques will deny exposure to asbestos is not surprising in view of its many uses, sometimes well camouflaged by other ingredients.

Practically all those with "asbestos cancers" were heavy smokers or ex-smokers. Thus elimination of smoking would probably be almost as effective in reducing such cancers as the elimination of asbestos. This fits with the model of multiplicative risks between asbestos and smoking shown in many investigations. $^{7-9}$

The relative increase in adenocarcinomas among people exposed to asbestos found in an earlier study $^{1}$ and by some other authors ${ }^{9}$ was not confirmed in the present investigation. The relative frequency of distribution was the same, however, with a tendency for asbestos lung cancers to be relatively more common in the lower lobes. The reason for this is obscure, as is the reason for non-asbestos cancers being situated mainly in the upper lobes. Asbestosis-that is, parenchymal fibrosis due to asbestos exposure, is also mainly situated in the lower lobes, which might have something to do with the distribution of lung cancers as well, but the vast majority of the patients in this series did not have radiologically or clinically manifest asbestosis. There are, however, possibly early though non-detectable changes which facilitate carcinogenesis.

Factors other than tobacco and asbestos seem of relatively little importance as judged from this series. This is probably also true for the rest of the industrialised world, even if there are local exceptions due to other agents. Since the latency for asbestos lung cancers is 37 years and there has been a steep rise in the use of asbestos since the second world war, it may be predicted that many more asbestos lung cancers will develop during the next few decades. Protective measures and regulations concerning the use of asbestos, though necessary, will unfortunately not result in lowering the figures for cancer until well into the next century. The fight against smoking will probably yield better and presumably quicker results. It is thus mandatory to inform all smokers exposed to asbestos of the risk that they are running and to do the utmost to get them to stop.

\section{References}

' Hillerdal G. Lung cancer-is the etiology changing? Cancer Detect Prev 1981;4:319-25.

${ }^{2}$ Nöu E, Hillerdal O. Total tobacco consumption in an unselected bronchial carcinoma population. Eur $J$ Respir Dis 1981;62:152-9.

${ }^{3}$ Doll R, Peto R. Mortality in relation to smoking: 20 years observation of male British doctors. $\mathrm{Br}$ Med J 1976;ii:1525-36.

4 Hirayama T. Non-smoking wives of heavy smokers have a higher risk of lung cancer: a study from Japan. Br Med J 1981;282:183-5.

${ }^{5}$ Hillerdal G. Pleural plaques in a health survey meterial. Frequency, development, and exposure to asbestos. Scand $J$ Respir Dis 1978;59:257-63.

${ }^{6}$ Hillerdal G, Hillerdal O, Nöu E. Radiologically visible pleural plaques in a one-year material from a health survey in 1976. Eur J Respir Dis 1980; suppl 107:89-98.

${ }^{7}$ McDonald AD, McDonald JC. Etudes épidémiologiques sur les maladies a l'amiante au Canada. Rev Fr Mal Respir 1976; suppl 2:25-38.

- Meurman LO, Kiviluoto R, Hakama M. Combined effects of asbestos exposure and smoking on Finnish anthophyllite miners and millers. Ann NY Acad Sci 1979;330:491-5.

'Hammond EC, Selikoff IJ, Seidman H. Asbestos exposure, cigarette smoking and death rates. Ann NY Acad Sci 1979;330:473-90. 